\title{
Direct and indirect actions of nutrients in the regulation of insulin secretion from the pancreatic $\beta$ cells
}

\author{
BY PETER R. FLATT, CHRISTOPHER R. BARNETT, \\ OMAR SHIBIER AND SARA K. SWANSTON-FLATT \\ Biomedical Sciences Research Centre and Department of Biological and Biomedical Sciences, \\ University of Ulster, Coleraine BT52 1SA, Northern Ireland
}

The ingestion and absorption of nutrients generates a spectrum of nutrient and non-nutrient stimuli which act on pancreatic $\beta$ cells to stimulate insulin secretion (Holst, 1991; Morgan, 1991). The direct actions of glucose, amino acids and fatty acids on $\beta$ cell function are complemented by neural and hormonal components of the entero-insular axis which are triggered in response to the ingestion, gastrointestinal processing and absorption of food components (Fig. 1).

Entero-insular stimuli amplify the insulin response of the $\beta$ cells to nutrient stimulation. However, the effectiveness of neural or hormonal stimulation is critically dependent on the prevailing level of glycaemia. Thus, glucose modulates $\beta$ cell responsiveness to virtually all stimuli, such that the insulin response is minimal at low glucose concentrations but is increasingly amplified in conditions of hyperglycaemia, such as encountered after feeding.

In the following sections, the mechanisms underlying the acute actions of nutrients and entero-insular stimuli on insulin secretion will be considered together with the ways in which the $\beta$ cells integrate the various signals to provide the appropriate secretory response.

\section{SECOND MESSENGERS FOR INSULIN SECRETION}

A number of intracellular messengers have been ascribed key roles in the stimulussecretion coupling of $\beta$ cells exposed to nutrients, hormones and neurotransmitter agents (Cook \& Taborsky, 1990; Rasmussen et al. 1990; Berggren et al. 1992). These include cytoplasmic calcium ions $\left(\left[\mathrm{Ca}^{2+}\right]_{i}\right)$, cyclic AMP formed by activation of adenylate cyclase (EC 4.6.1.1) and two products generated following activation of phospholipase $\mathrm{C}$ (EC 3.1.4.3), namely myo-inositol 1,4,5-trisphosphate $\left(\operatorname{Ins}(1,4,5) \mathrm{P}_{3}\right)$ and diacylglycerol.

Of these messengers, $\left[\mathrm{Ca}^{2++}\right]_{i}$ is recognized as the principal regulator of insulin secretion (Berggren et al. 1992; Hellman et al. 1992). Thus, an increase in $\left[\mathrm{Ca}^{2+}\right]_{\mathrm{i}}$ is believed to trigger insulin discharge by decreasing electrostatic repulsion between the secretory granule and plasma membrane, and by activating the microtubule-microfilament system for exocytosis (Howell, 1991). There is also evidence that $\mathrm{Ca}^{2+}$ influx activates phospholipase $\mathrm{C}$, and that binding of the cation to $\mathrm{Ca}^{2+}$-sensitive cellular proteins such as calmodulin activates various other enzyme systems including adenylate cyclase (Hughes \& Ashcroft, 1992; Morgan \& Montague, 1992). Cytoplasmic $\mathrm{Ca}^{2+}$, therefore, amplifies its insulinotropic action within the $\beta$ cell by the production of complementary second messengers. Generation of $\operatorname{Ins}(1,4,5) \mathrm{P}_{3}$ is believed to enhance $\left[\mathrm{Ca}^{2+}\right]_{\mathrm{i}}$ by mobilizing $\mathrm{Ca}^{2+}$ from intracellular stores (i.e. endoplasmic reticulum; Morgan \& Montague, 1992). Diacylglycerol, by activating protein kinase C (EC 2.7.1.37), is 


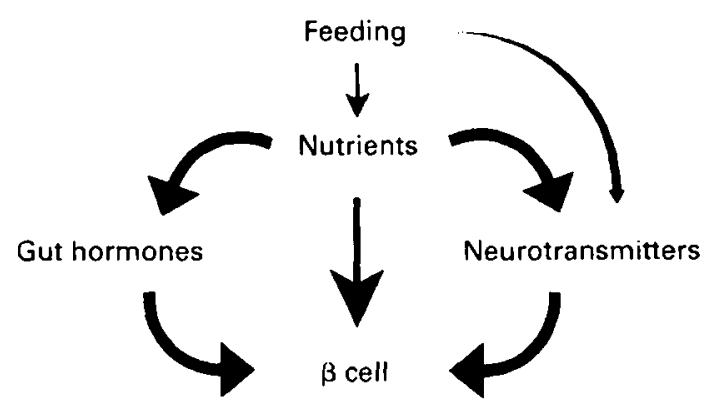

Fig. 1. Direct and indirect actions of nutrients on insulin-secreting pancreatic $\beta$ cells.

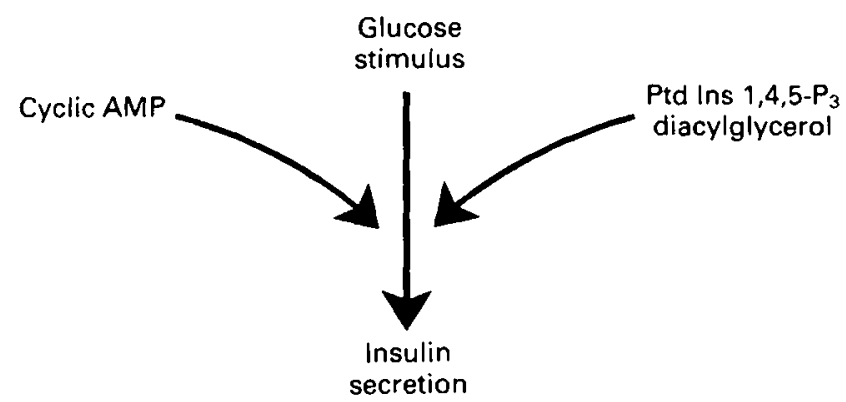

Fig. 2. Amplification of the glucose stimulus to insulin secretion by second messengers generated by adenylatc cyclase ( $E C$ 4.6.1.1) and phospholipase $\mathrm{C}\left(E C\right.$ 3.1.4.3). Ins 1,4,5- $\mathrm{P}_{3}$, myo-inositol 1.4.5-trisphosphate.

proposed to sensitize the secretory process to $\mathrm{Ca}^{2+}$ (Berggren et al. 1992; Persaud et al. 1992). This latter action is also shared by cyclic AMP which additionally serves to activate microtubule-microfilament-associated protein kinases (Hughes \& Ashcroft, 1992).

As will become evident from later discussions, glucose and other nutrients (certain amino acids) directly stimulate insulin secretion primarily by increasing $\left[\mathrm{Ca}^{2+}\right]_{\mathrm{i}}$. Neural and hormonal entero-insular stimuli amplify glucose-induced insulin secretion through the activation of adenylate cyclase or phospholipase $\mathrm{C}$ with generation of cyclic AMP or Ins(1,4,5) $\mathrm{P}_{3}$ and diacylglycerol (Fig. 2).

\section{ACTIONS OF NUTRIENTS}

1. Glucose and other sugars. Glucose and mannose are the only sugars which directly stimulate insulin secretion, although sugars such as galactose elicit an insulin response following activation of the entero-insular axis with the release of insulinotropic agents such as gastric inhibitory peptide (GIP) (Ashcroft, 1980; Malaisse, 1983; Morgan, 1992). In view of the crucial role of glucose as the primary insulin secretagogue which also modulates the insulinotropic potency of other stimulators, considerable attention has been devoted to its mechanism of action on pancreatic $\beta$ cells.

It is now established that the insulin-releasing effect of glucose (like that of mannose) stems from the ability of the $\beta$ cells to transport and metabolize the sugar (Malaisse, 


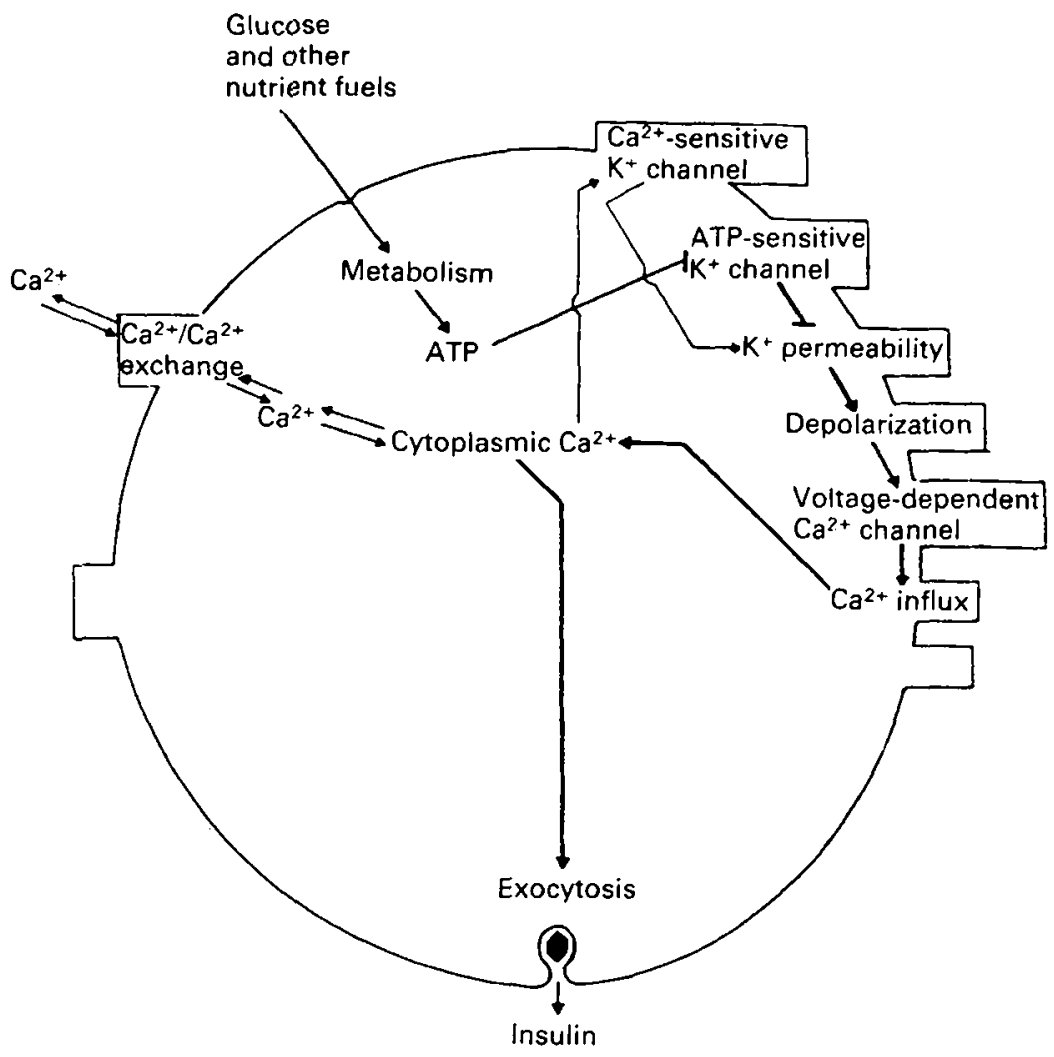

Fig. 3. Actions of glucose and other nutrient fuels on the insulin secretory process. (Adapted from Flatt \& Bailey. 1991.)

1992). As shown in Fig. 3, exposure to glucose has been shown to cause a rapid increase in ATP and the ATP:ADP ratio. This leads to inhibition of ATP-sensitive potassium ion channels in the $\beta$ cell membrane, decreased $\mathrm{K}^{+}$permeability, depolarization and the opening of voltage-dependent $\mathrm{Ca}^{2+}$ channels (Ashcroft et al. 1992; Henquin et al. 1992). Although the stimulation of $\mathrm{Ca}^{2+}$ influx in the $\beta$ cells is associated with increases in both $\mathrm{Ca}^{2+}$ sequestration by organelles and $\mathrm{Ca}^{2+}$ efflux, measurements using $\mathrm{Ca}^{2+}$-fluorescent dyes have unequivocally demonstrated that glucose evokes a rapid rise of $\left[\mathrm{Ca}^{2+}\right]_{i}$ (Hellman et al. 1992). This increase in $\left[\mathrm{Ca}^{2+}\right]_{i}$ is believed to trigger exocytosis as previously outlined. However, an additional action of elevated $\left[\mathrm{Ca}^{2+}\right]_{i}$ is to activate $\mathrm{Ca}^{2+}$-sensitive $\mathrm{K}^{+}$channels. This action together with related effects on other ion channels leads to repolarization of the plasma membrane (Ashcroft et al. 1992; Henquin et al. 1992). In the presence of a continuing glucose stimulus, the repolarization phase is rapidly followed by successive cycles of depolarization-repolarization with corresponding episodes of $\mathrm{Ca}^{2+}$ influx and insulin release (Hellman et al. 1992; Henquin et al. 1992).

2. Amino acids. Various amino acids directly stimulate insulin secretion, although considerable differences exist in their potency and the mechanisms through which they 
may ultimately increase $\left[\mathrm{Ca}^{2+}\right]_{\mathrm{i}}$ to trigger exocytosis (Gerich et al. 1976; Henquin, 1987). Leucine, arginine and lysine are considered as the most potent stimulators, but alanine, glycine, tryptophan, aspartate, isoleucine, asparagine and phenylalanine have also been reported to exert stimulatory effects, albeit at high concentrations (Gerich et al. 1976). Of these amino acids, only leucine is capable of stimulating insulin secretion in the absence of glucose (Henquin \& Meissner, 1981, 1986). Thus, the insulinotropic actions of amino acids are very much dependent on the conjoint stimulation of $\beta$ cell function together with glucose and the various entero-insular stimuli. GIP is unlikely to play a significant role in this respect (Flatt et al. 1991), but cholecystokinin (CCK) and glucagon-like peptide 1 (GLP-1(7-36)) released from entero-endocrine cells might be important. Furthermore. since many amino acids are potent stimulators of glucagon secretion (Gerich et al. 1976; Assan et al. 1983), activation of pancreatic $\alpha_{2}$ cells will markedly amplify the insulin response.

Studies using leucine, arginine, lysine and alanine have demonstrated three basic mechanisms which appear to underlie the effects of amino acids on insulin release (Hellman et al. 1971: Henquin \& Meissner, 1981, 1986; Charles \& Henquin, 1983; Henquin, 1987). Leucine is transported into the $\beta$ cells where it is metabolized, giving rise to qualitatively similar changes in membrane potential and ionic fluxes as described for glucose (Fig. 3). Generation of ATP almost certainly underlies these actions since the first catabolic product of leucine metabolism, 2-ketoisocaproate, has been reported to stimulate insulin release, increase ATP and inhibit ATP-sensitive $\mathrm{K}^{+}$channels in $\beta$ cells (Ashcroft et al. 1987). The effects of arginine and lysine on insulin release are quite different from that of leucine in that these amino acids are not metabolized, and enter the $\beta$ cells through a transport system specific for cationic amino acids. However, the $\beta$ cell membrane is depolarized by the transport of these positively charged amino acids leading to the opening of voltage-dependent $\mathrm{Ca}^{2+}$ channels and $\mathrm{Ca}^{2+}$ influx (Henquin, 1987). In contrast to leucine, arginine and lysine, alanine is a weak stimulator of insulin release and is poorly metabolized by $\beta$ cells (Hellman et al. 1971). Alanine is taken up by the $\beta$ cell in association with sodium ion entry, and the insulinotropic activity of the amino acid appears to relate to the ability of the co-transported $\mathrm{Na}^{+}$to elevate $\left[\mathrm{Ca}^{2+}\right]_{i}$ due to mobilization of cellular $\mathrm{Ca}^{2+}$ and inhibition of $\mathrm{Na}^{+}-\mathrm{Ca}^{2+}$ exchange (Henquin. 1987).

3. Free fatty acids and ketone bodies. Certain free fatty acids and ketone bodies exert modest stimulatory effects on $\beta$ cell function in the presence of glucose. Thus, high concentrations of short-chain fatty acids (butyrate, octanoate, propionate and valerate), long-chain fatty acids (oleate and palmitate) and ketone bodies (acetoacetate and 3-hydroxybutyrate) have been reported to stimulate insulin release (Gerich et al. 1976). Relatively little effort has been devoted to the mechanism underlying the acute actions of free fatty acids or their oxidation products. Presumably, their insulin-releasing effect stems from the ability of the $\beta$ cells to metabolize these agents. However, experiments with the ketone bodies suggest no simple relationship between oxidation and their relative abilities to stimulate insulin release (Biden \& Taylor, 1983).

Although the physiological significance of direct effects of free fatty acids on $\beta$ cell function is open to question, there is no doubt that activation of the entero-insular axis by certain free fatty acids markedly amplifies the insulin response to glucose stimulation. Long-chain unsaturated free fatty acids are especially potent stimulators of GIP release (Kwasowski et al. 1985). Furthermore, free fatty acids are believed to play important 
longer-term roles in $\beta$ cell function including the synthesis of triacylglycerols and phospholipids which may serve as endogenous $\beta$ cell fuels or be utilized for the generation of second messengers including $\operatorname{Ins}(1,4,5) \mathrm{P}_{3}$ and diacylglycerol (Best \& Malaisse, 1983; Morgan \& Montague, 1992).

4. Other nutrients. With a few notable exceptions, ingested minerals, vitamins and trace elements have no major acute physiological effects on insulin secretion. However, the role of dietary calcium as a stimulator and modulator of the secretions of both the entero-insular axis and pancreatic $\beta$ cells has been largely overlooked. Thus, an increase in extracellular $\mathrm{Ca}^{2+}$ following absorption may directly modulate insulin secretion, and changes in $\mathrm{Ca}^{2+}$ have clearly been shown to amplify or restrict the stimulatory actions of other secretogogues including glucose (Hellman et al. 1992). The mechanism of action of extracellular $\mathrm{Ca}^{2+}$ in this respect is to modify resting and stimulated $\left[\mathrm{Ca}^{2+}\right]_{i}$ in the $\beta$ cells.

Although it is theoretically possible for other minerals and trace elements to modify insulin secretion by interference with $\beta$ cell membrane potential or the processes of $\mathrm{Ca}^{2+}$ influx and exchange (Flatt $e t$ al. 1987), this is unlikely to be of physiological significance. However, it is not unreasonable to envisage such effects in conditions of prolonged deficiency or acute toxicological excess. Similarly, certain vitamin deficiencies may impair insulin secretion, and there is particular evidence for a role of vitamin D metabolites in the longer-term modulation of $\beta$ cell function (Norman et al. 1980). Such an action is clearly related to stimulatory role of $\left[\mathrm{Ca}^{2+}\right]_{i}$ in the insulin secretory mechanism.

\section{ACTIONS OF ENTERO-INSULAR STIMULI}

1. Neurotransmitter agents. The pancreatic islets receive a rich innervation from the parasympathetic and sympathetic divisions of the autonomic nervous system (Holst, 1992). Although experiments involving the transplantation of denervated islets into diabetic recipients do not suggest a major role of neural innervation in the insulin response to feeding, it has been established that cholinergic activation makes an important contribution to the normal stimulus-secretion coupling process (Holst, 1992). Consistent with this view, resection and electrical stimulation of the vagus nerve have opposite effects on insulin secretion and both the classical cholinergic neurotransmitter, acetylcholine and the neuropeptide. CCK, augment insulin secretion in a glucosedependent manner (Berggren et al. 1992; Holst, 1992). The mechanism of action of these neurotransmitters is illustrated in Fig. 4. Both agents bind to receptors on the $\beta$ cell membrane, activate phospholipase $\mathrm{C}$ and generate two intracellular messengers namely, Ins $(1,4,5) \mathrm{P}_{3}$ and diacylglycerol (Berggren et al. 1992). These act to increase $\left[\mathrm{Ca}^{2+}\right]_{\mathrm{i}}$ by mobilization of $\mathrm{Ca}^{2+}$ from intracellular stores and to sensitize the secretory machinery to $\left[\mathrm{Ca}^{2+}\right]_{\mathrm{i}}$. In addition to this direct action on $\beta$ cells, cholinergic agents may further amplify insulin release by stimulation of pancreatic $\alpha_{2}$ cell glucagon secretion (Gerich $e t$ al. 1976). Cholinergic activation may also be associated with the release of insulinotropic peptides from other peptidergic nerve terminals reported to contain vasoactive intestinal peptide (VIP), peptide histidine isoleucine (PHI) and gastrin-releasing polypeptide (GRP) (Holst, 1992). Some of these peptides are also secreted from endocrine cells in the gut in response to nutrients (Walsh, 1987; Morgan, 1992).

2. Gut hormones. As previously discussed, a large number of hormones have been implicated as entero-insular stimuli on the basis of their abilities to stimulate insulin 


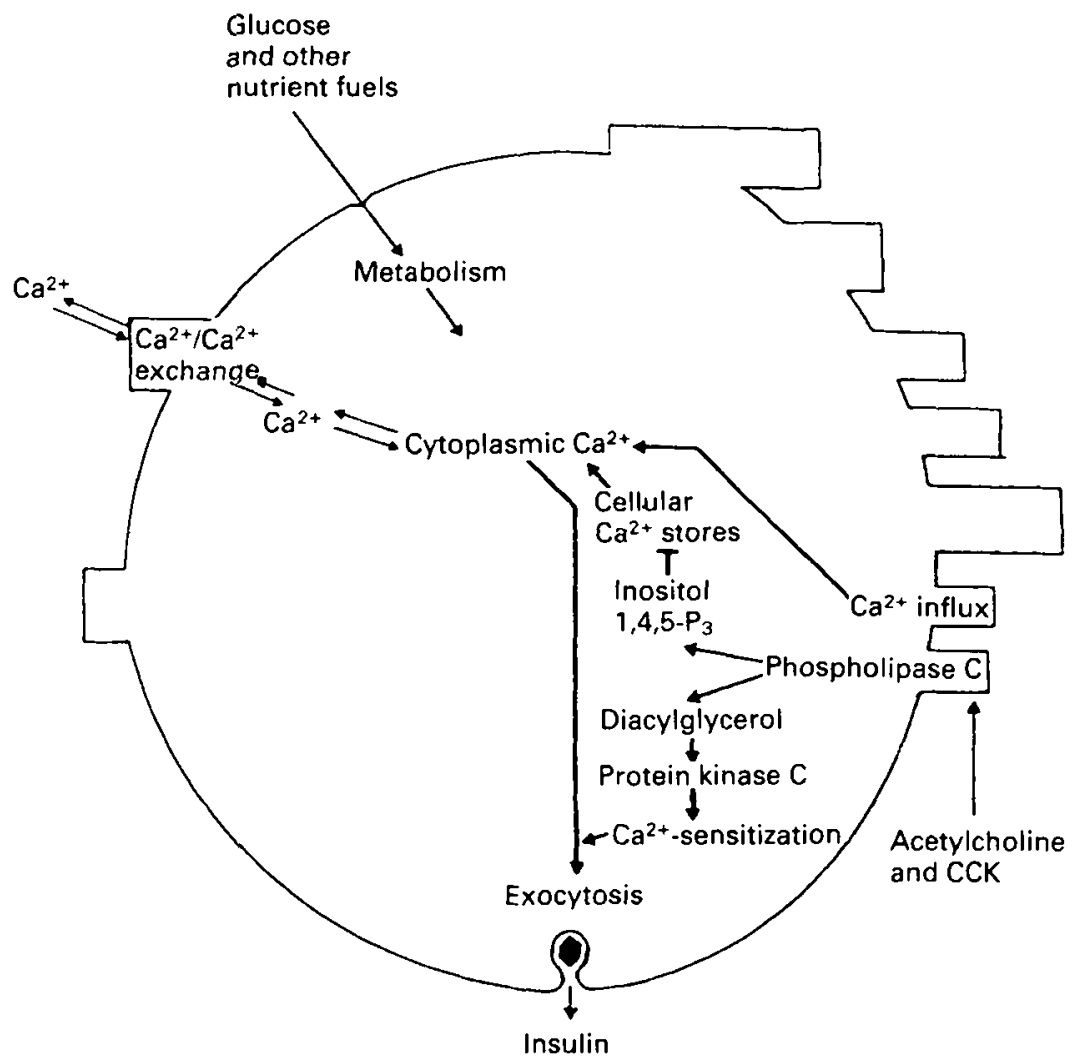

Fig. 4. Actions of acetylcholine and cholecystokinin (CCK) on the insulin secretory process mediated by phospholipase C (EC 3.1.4.3). (Adapted from Flatt \& Bailey, 1991.)

secretion from pancreatic $\beta$ cells in the presence of glucose (Walsh, 1987; Morgan. 1992). Interpretation of these findings is complicated by many factors including species differences, peptide impurity, peptide instability, loss of functional receptors on collagenase-isolated islet cells and the use of supra-physiological peptide concentrations. Furthermore, the recent discovery and relative scarcity of some of these peptides means that caution must be used when interpreting the results of a necessarily limited number of studies. Thus, the significance and mode of action are established for only a small number of entero-insular hormones.

In the cases of glucagon and GIP, it has been clearly demonstrated that these hormones bind to specific receptors on the $\beta$ cells, leading to the activation of adenylate cyclase, accumulation of cyclic AMP and amplification of the insulin response to glucose (Berggren et al. 1992). The actions of GIP and glucagon-like peptides are illustrated in Fig. 5. In contrast, $\mathrm{CCK}$ activates phospholipase $\mathrm{C}$ and also amplifies the $\mathrm{Ca}^{2+}$ signal for exocytosis (Fig. 4), although in a different way to cyclic AMP. The entero-insular hormones, therefore, appear to exploit both amplification systems for insulin release, and it is not unreasonable to expect the less-well-researched hormones to fit into one of these mechanisms of action. 


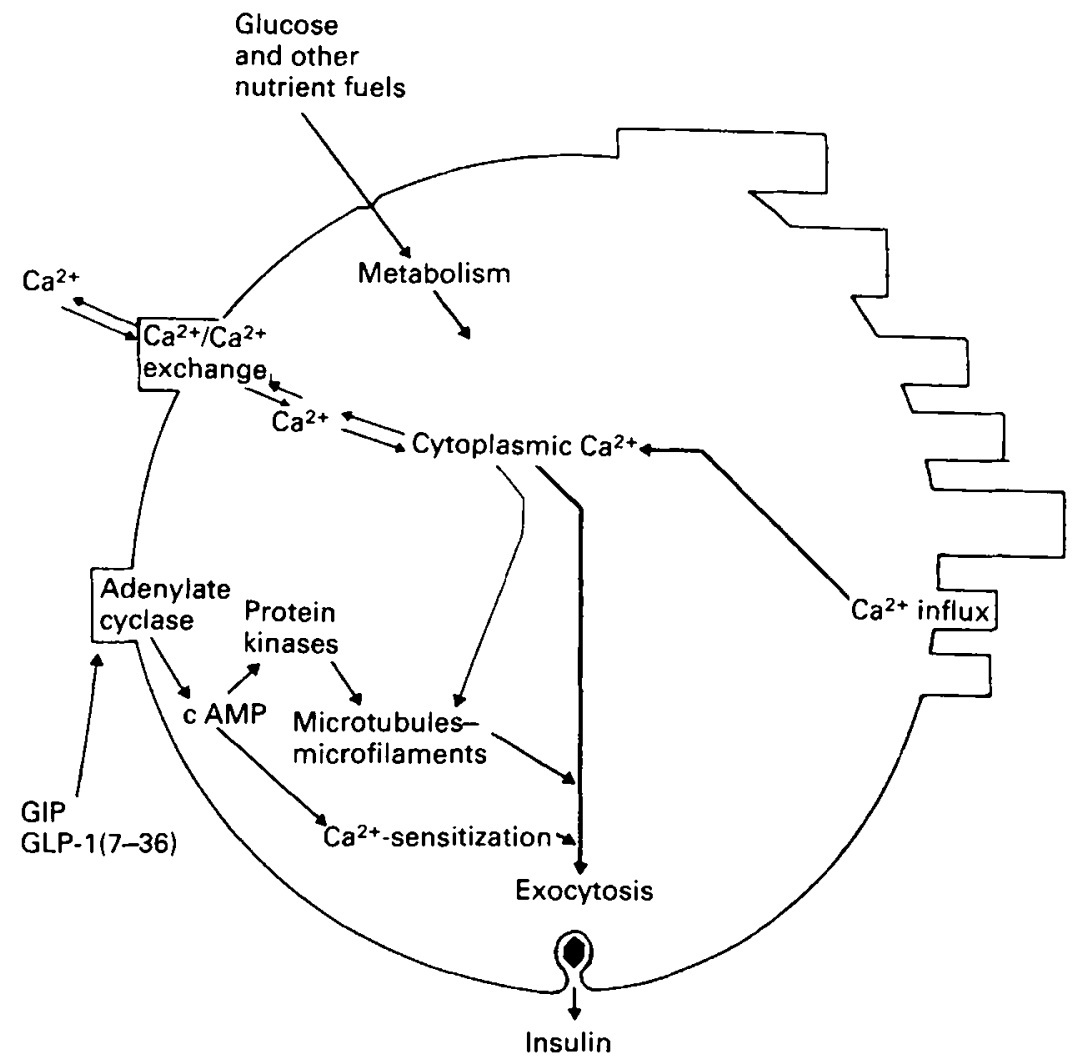

Fig. 5. Actions of gastric inhibitory polypeptide (GIP) and glucagon-like peptides (GLP) on the insulin secretory process mediated by adenylate cyclase ( $E C$ 4.6.1.1). (Adapted from Flatt \& Bailey, 1991.)

\section{REFERENCES}

Ashcroft, F. M., Ashcroft, S. J. H. \& Harrison, D. E. (1987). Effects of 2-ketoisocaproate on insulin release and single channel activity in dispersed rat pancreatic $\beta$-cells. Journal of Physiology 385, 517-529.

Ashcroft, F. M., Williams, B., Smith, P. A. \& Fewtrell, C. M. S. (1992). Ion channels involved in the regulation of nutrient-stimulated insulin secretion. In Nutrient Regulation of Insulin Secretion, pp. 193-212 [P. R. Flatt, editor]. London: Portland Press.

Ashcroft, S. J. H. (1980). Glucoreceptor mechanisms and the control of insulin release and biosynthesis. Diabetologia 18, 5-15.

Assan, R., Marre, M. \& Gormley, M. (1983). The amino acid-induced secretion of glucagon. In Glucagon II, pp. 19-41 [P. J. Lefebvre, editor]. Berlin: Springer-Verlag.

Berggren, P.-O., Rorsman, P.. Efendic, S., Östenson, C.-G.. Flatt, P. R., Nilsson, T., Arkhammar, P. \& Juntti-Berggren, L. (1992). Mcchanisms of action of enteroinsular hormones, islet peptides and ncural input on the insulin secretory process. In Nutrient Regulation of Insulin Secretion, pp. 289-318 [P. R. Flatt. editor]. London: Portland Press.

Best, L. \& Malaisse, W. J. (1983). Phospholipids and islet function. Diabetologia 25, 299-305.

Biden, T. J. \& Taylor, K. W. (1983). Effects of ketone bodies on insulin release and islet-cell metabolism in the rat. Biochemical Journal 21, 371-377

Charles, S. \& Henquin, J. C. (1983). Distinct effects of various amino acids on ${ }^{45} \mathrm{Ca}^{2+}$ fluxes in rat pancreatic islets. Biochemical Journal 214, 899-907.

Cook, D. L. \& Taborsky, G. J. (1990). $\beta$-cell function and insulin secretion. In Ellenberg and Rifkin's Diabetes Mellitus: Theory and Practice, 4th ed., pp. 89-103 [H. Rifkin and D. Porte Jr, editors]. New York: Elsevier. 
Flatt, P. R. \& Bailey, C. J. (1991). Molecular mechanisms of insulin secretion and insulin action. Journal of Biological Education 25, 9-14.

Flatt, P. R., Kwasowski, P., Howland, R. J. \& Bailey, C. J. (1991). Gastric inhibitory polypeptide and insulin response to orally administered amino acids in genetically obese hyperglycaemic $(o b / o b)$ micc. Journal of Nutrition 121, 1123-1128.

Flatt, P. R. Rorsman, P. \& Swanston-Flatt. S. K. (1987). Effects of cationic modification on superficial binding and intracellular ${ }^{45} \mathrm{Ca}$ uptake by decapsulated ob/ob mouse pancreatic islets. Biomedical Research 8, 153-159.

Gerich, J. E., Charles, M. A. \& Grodsky, G. M. (1976). Regulation of pancreatic insulin and glucagon secretion. Annual Review's of Physiology 38, 353-388.

Hellman, B., Gylfe, E.. Grapengiesser, E., Lund, P.-E. \& Marcström, A. (1992). Cytoplasmic calcium and insulin secretion. In Nutrient Regulation of Itsulin Secretion, pp. 213-246 [P. R. Flatt. cditor]. London: Portland Press.

Hellman. B.. Schlin. J. \& Taljedal, I. B. (1971). Effects of glucose and other modifiers of insulin relcase on the oxidative metabolism of amino acids in micro-dissected pancreatic islets. Biochemical Journal 123, 513-521.

Henquin, J. C. (1987). Regulation of insulin release by ionic and electrical events in $\beta$-cells. Hormone Research 27, $168-178$.

Henquin, J. C., Debuyser, A., Drews, G. \& Plant, T. D. (1992), Regulation of K- permeability and membrane potential in insulin-secreting cells. In Nutrient Regulation of Insulin Secretion. pp. 173-192 [P. R. Flatt, editor]. I.ondon: Portland Press.

Henquin. J. C. \& Meissner, H. P. (1981). Effects of amino acids on membrane potential and ${ }^{\text {kn }} \mathrm{Rb}^{-}$fluxes in pancreatic $\beta$ cells. American Journal of Physiology 240. E245-F:252.

Henquin, J. C. \& Meissner, H. P. (1986). Cyclic adenosine nonophosphate differentially affects the response of mouse pancreatic $\beta$-cells to various amino acids. Journal of Physiology 381, 77-93.

Holst, J. J. (1992). Role of classical and peptidergic neurotransmitters in insulin secretion. In Nutrient Regulation of Insulin Secretion. pp. 23-40 |P. R. Flatt. editor]. London: Portland Press.

Howell, S. L. (1991). Insulin biosynthesis and secretion. In Textbook of Diabetes, vol. 1, pp. $72-83$ [J. C. Pickup and G. Williams, cditors]. London: Blackwell Scientific Publications.

Hughes, S. J. \& Ashcroft, S. J. H. (1992). Cyclic AMP, protein phosphorylation and insulin secretion. In Nutrient Regulation of Insulin Secretion, pp. 271-288 [P. R. Flatt. editor]. L.ondon: Portland Press.

Kwasowski, P., Flatt, P. R., Bailey, C. J. \& Marks, V. (1985). Effects of fatty acid chain length and saturation on gastric inhibitory polypeptide release in obese hyperglycaemic $(o b / o b)$ mice. Bioscience Reports 5 , $701-705$.

Malaisse, W. J. (1983). Insulin release: The fuel concept. Diabète et Métabolisme 9, 313-320.

Malaisse, W. J. (1992). Regulation of insulin secretion by nutrients: D-glucose metabolism in islet cells. In Nutrient Regulation of Insulin Secretion. pp. 83-100 [P. R. Flatt, editor]. London: Portland Press.

Morgan, L. M. (1992). Insulin secretion and the enteroinsular axis. In Nutrient Regulation of Instilin Secretion, pp. 1-22 [P. R. Flatt, editor]. London: Portland Press.

Morgan, N. G. \& Montague, W. (1992). Phospholipids and insulin secretion. In Nutrient Regulation of Insulin Secretion, pp. 125-156 [P. R. Flatt, editor]. London: Portland Press.

Norman, A. W., Frankel, B. J.. Heldt, A. M. \& Grodsky, G. M. (1980). Vitamin D deficiency inhibits pancreatic secretion of insulin. Science 209, 823-825.

Persaud, S. J., Jones, P. M. \& Howell, S. J. (1992). The role of protein kinase C in insulin secretion. In Nutrient Regulation of Insulin Secretion, pp. 247-270 [P. R. Flatt, cditor]. London: Portland Press.

Rasmussen, H., Zawalich, K. C., Ganesan, S., Calle, R. \& Zawalich, W. S. (1990). Physiology and pathophysiology of insulin secretion. Diabetes Care 13, 655-666.

Walsh, J. H. (1987). Gastrointestinal hormones. In Physiology of the (jastrointestinal Tract, 2nd ed., pp. 181-253 [L. R. Johnson, editor]. New York: Raven Press. 